\title{
Female fish farmers: How technically efficient are they? Evidence from Delta State Nigeria
}

\section{Theophilus Miebi GBIGBI}

Cite this article as:

Gbigbi, T.M. (2021). Female fish farmers: How technically efficient are they? Evidence from Delta Satte Nigeria. Aquatic Research, 4(3), $250-259$. https://doi.org/10.3153/AR21019

Delta State University, Department of Agricultural Economics and Extension, Asaba Campus, Asaba

ORCID IDs of the author(s): T.M.G. 0000-0002-1335-7231

Submitted: 13.11 .2020

Revision requested: 18.01 .2021

Last revision received: 21.01 .2021

Accepted: 23.01.2021

Published online: 29.04 .2021

Correspondence:

Theophilus Miebi GBIGBI

E-mail: gbigbitheophilusmiebi@yahoo.com

\begin{abstract}
The study investigated the technical efficiency of female catfish growers in Delta State, Nigeria. Data have been obtained using questionnaires from 112 female catfish farmers who have been randomly selected. Descriptive statistics, cost and return analysis as well as the stochastic model have been used in the analysis of data. The results showed that the mean age, farming experience and household size of the female fish farmers were 42 years old, 8 years and 6 persons respectively. Most of the participants are married and educated. The gross margin and net farm income were N490,378.46 and N416,242.82k respectively. With a rate of return on investment and a BCR (Benefit Cost Ratio) of 0.64 and 1.64, fish farming was found to be profitable. The Stochastic frontier outcome showed that the size of the pond, fingerlings, feed and water supply had a significant and positive effect on fish production, while the cost of medication had an inverse relationship with fish production. Age, education and household size have been found to increase technical performance, while technical inefficiency is increased by distance from farm location and credit access. The finding further revealed that a female fish farmer had a technical efficiency of $53.5 \%$ in the area of study. This is a signal that by implementing the technologies practiced by the best farmers, fish productivity can be improved by about $46.5 \%$ by the farmers. The coefficient of elasticity was 0.567, which indicated that the female catfish farmers were in Phase II. The failure of farmers to reach the production frontier may however be due to certain factors, including insufficient funding, high feed costs, water supply and fingerlings shortages. On the basis of the results, female fish farmers should be supported by means of professional training in fish production practices to ensure that their resources are optimally utilized.
\end{abstract}

Keywords: Technical efficiency, Female farmers, Fish farming, Profitability

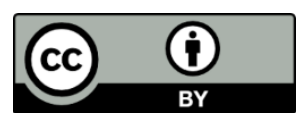

(C) 2021 The Author(s) 


\section{Introduction}

Fish farming is one of the very important agricultural activities; hence, it holds a strategic role in the economy. Its contribution to the agricultural share of the gross domestic product (GDP) was estimated at $1.3 \%$ in 2010 , with agriculture contributing $40.9 \%$ of the overall estimate to GDP (CBN, 2011).

Nigeria has substantial coastline of around $853 \mathrm{~km}$ contiguous the Atlantic Ocean and more than 14 million hectares of inland water with 75 percent being relatively suitable, and about $112,085 \mathrm{~km} 2$ are considered to be very suitable for development of aquaculture. The production of fish as a business has the potential to make a substantial contribution to the agrarian sector of the economy (FDF, 2007).

Observations showed that the demand of fish in Nigeria exceeds their availability. Despite the large number of water resources and manpower available, domestic production is very poor. Annual fish consumption and demand were estimated in Nigeria at over 1.3 million tons, and total domestic production was put at just approximately 407,869 tons per year (Tsadu et al. 2006).

Recently, over-exploitation of fisheries resources through heavy-duty fishing machines and capture equipment has become a serious issue, resulting in fish shortages and the need to increase fisheries production by fish farming (Eyo, 2003). Silvestre et al. (2003) argued that coastal fish stocks decreased through over-exploitation to $30 \%$ of their untapped levels. The effect is that poor coastal fishermen who depend solely on these services remain poverty-stricken. These concerns call for government response to sustainable fish availability to satisfy domestic demand by importing more than 288 billion naira per annum, which has not been reached (Central Bank of Nigeria, 2017). This gap needs to be covered hence the need to make up for the shortfall experienced.

Nigeria should replace fish importations by domestic production in order to bridge the gap between demand and supply with women's involvement in fish farming to build employment and minimize poverty (Shester and Micheli, 2011).

Further, it creates direct and indirect job opportunities for people engaged in the production of fish and for those engaged in other related enterprises, thus contributing to national income for all groups of folks engaged in fish farming. It takes less time, space, money and a higher feed conversion rate compared to livestock. Thus, fish farming has become a crucial endeavour, in particular for children, in order to ensure food security and to fight malnutrition (FAO, 2017).

Aquaculture is the fastest-growing food-producing sub-sector of the world, according to the World Fish Center (2009), with an annual growth of 8.9 percent since 1970 . The major species cultured in Nigeria include tilapias, catfish and carp. However, the African catfish species Clarias gariepinus (Burchell, 1822) has been given much attention in Nigeria because of its prolificity and its quick growth potential to bridge the gap in demand. Adebayo and Daramola (2013) asserted that it is the largest species grown in Nigeria. Catfish (C. gariepinus) is highly resilient to disease and has a relative low production cost and feeding habit that makes it very easy to earn a huge profit on investment.

FAO (2003) was of the opinion that any nation's development process is decided by the development of its women and the extent of involvement of these women in the nations various farming activities, including fish farming.

The nation's population provides an essential labour force which can turn fish farming in the nation into increased fish output in order to boost household and income generating jobs. It is generally agreed that, due to their social and economic positions, women participate strongly in the rural economy and are not left out of culture fish production.

Women folks are the mainstay of the labour force in agricultural production that generates about 40 percent of gross domestic product (GDP) and more than 50 percent of food produced in developing nations (Ani, 2004). This is confirmed by Adenugba and Raji-Mustapha (2013) found that women offer about 60-80 percent of agrarian labour and contribute approximately 80 percent of Nigeria's food production.

Participation in this context connotes the physical involvement 'of women in fish farming activities in order to increase efficiency in fish production and household income.

Women's involvement in aquaculture extends to all aspects of fish farming such as feed preparation, fish feeding, net/cage cleaning, pond maintenance and fish processing (Krushelnytska, 2015). Women's positions were either ignored or undervalued in fish farming (Cohen et al. 2016., Parks et al. 2015).

Unlike other enterprises, such as arable crop production and poultry production, which are engaging both male and female farmers, involvement of females in fish production is not known. Nevertheless, it is commonly conceived, with regard to fish production, that fish farming is culturally restricted to men. Thus, the involvement level of women folk in fish farming is far too low to meet the nation's protein needs.

It is estimated that $60 \%$ of the fish consumed are catfish and are gradually adding to the industry, which remains primarily a live fish market to date. According to Ekunwe and Emokaro (2009), a significant amount of fish farmers have recently 
concentrated on catfish because it can have 2-3 times the market value of tilapia in greater part of Nigeria owing to its market demand.

Furthermore, women's low fish production is due mainly to economic, financial, operational and technical obstacles, retarding the pace of development in the fishery sub-sector to the minimum level. It is suspected that their technical efficiency level is the major reason for the poor production level. A panacea for evaluating the capacity for sustainable aquaculture development would be to evaluate the technical efficiency level by identifying the significant factors related with efficient production systems (Gbigbi, 2019).

Recent studies in estimating women-in-agriculture and efficiency are centered on crop and livestock production with limited information on female catfish farmers technical efficiency (Adewale and Ikeola 2005, Ani 2004., Tulchan and Karki 2000). Similarly (Baruwa and Omodara 2019., Gbigbi, 2017 and Idoge et al. 2017) carried out investigation on catfish farming in Delta State. To the best of my knowledge, none of the researchers focus on technical efficiency and female catfish farmers in the area. Therefore, it becomes necessary to estimate the efficiency level of the women to see if the business is profitable and sustainable. Thus, this research was undertaken to bridge the knowledge gap by providing information on proper adjustment in resource utilization in catfish farming by women, which would in turn lead to increase in their income and standard of living.

The specific objectives are to:

i. Describe the socio-economic features of the female catfish farmers

ii. Examine the cost and return of female catfish farmers

iii. Estimate the determinants of technical efficiency of female catfish farmers

iv. Ascertain the technical efficiency level of female catfish farmers

v. Estimate the elasticity and return to scale of female catfish farmers

vi. Ascertain the constraints of female catfish farmers

\section{Material and Methods}

\section{Study Area}

Delta State is the study area for the research. For this study, primary data have been obtained. The key data were collected with a questionnaire from the field survey. The map of the study area is presented in Table 1. Data on the efficiency of females catfish production determinants, the structure of cost and return and inputs used in catfish production in the area under study were especially investigated.

\section{Sampling Techniques}

A three-stage sampling procedure was used in drawing the survey respondents. Delta State is demarcated into three agricultural zones namely: Delta north, Delta central and Delta south. Delta south and central agricultural zones have 8 extension blocks each, while Delta north agricultural zone comprises 9 extension blocks. Firstly, four agricultural blocks were randomly selected from each of the three agricultural zones. The second stage involved selection of two cells from each block. Finally, from each of the cells selected, 14 women folk in catfish production were carefully chosen. This will give us 112 respondents at the end.

\section{Methods of Data Analysis}

Both descriptive and quantitative tools were engaged in data analysis. While descriptive statistics were applied to encapsulate the socioeconomic attributes of the women in fish farming, gross margin analysis was used to examine the costs and return from fish farming enterprise. Determinants of technical efficiency and inefficiency of women in fish farming were estimated with stochastic frontier.

\section{Model Specification}

The specified production function is of the form:

$\operatorname{In} Y=\beta_{0}+\beta_{1} \ln X_{1}+\beta_{2} \ln X_{2}+\beta_{3} \ln X_{3}+\beta_{4} \ln X_{4}+\beta_{5} \ln X_{5}+$ $\beta_{6} \ln \mathrm{X}_{6}+\left(\mathrm{V}_{\mathrm{i}}-\mathrm{U}_{\mathrm{i}}\right) \ldots(1)$

\section{Where:}

$\mathrm{Y}=$ Total fish output $(\mathrm{kg})$

$\mathrm{X}_{1}=$ pond size $(\mathrm{m} 2)$

$\mathrm{X}_{2}=$ labour used (mandays)

$\mathrm{X}_{3}=$ fingerlings(Number of fingerlings)

$\mathrm{X}_{4}=$ quantity of feed $(\mathrm{kg})$

$\mathrm{X}_{5}=$ cost of medication $(\$)$

$\mathrm{X}_{6}=$ water supply(litres)

$\mathrm{B}_{\mathrm{o}}=$ Intercept

$\mathrm{Bs}=$ Vector of the coefficients for the associated independent variables in the production function

$\mathrm{U}_{\mathrm{i}}=$ one sided components, which captures deviation from frontier as a result of inefficiency of the firm $V_{i}=$ effect of random stocks outside the firm control, observation and measurement error and other stochastic (noise) error term.

The inefficiency model is expressed as:

$\mathrm{U}_{\mathrm{i}}=\delta_{\mathrm{o}}+\delta_{1} \mathrm{Z}_{1}+\delta_{2} \mathrm{Z}_{2}+\delta_{3} \mathrm{Z}_{3}+\delta_{4} \mathrm{Z}_{4}+\delta_{5} \mathrm{Z}_{5}+\delta_{6} \mathrm{Z}_{6}$ 
$\mathrm{Z}_{1}=$ age (years)

$\mathrm{Z}_{2}=$ education (years)

$\mathrm{Z}_{3}=$ household size

$\mathrm{Z}_{4}=$ farming experience (years)

$\mathrm{Z}_{5}=$ distance of farm from residence $(\mathrm{km})$

$\mathrm{Z}_{6}=$ access to credit obtained (yes $=1$, otherwise $=0$ )

$\delta_{1}-\delta_{6}=$ are the scalar parameters to be estimated

Profitability of female cattish farmers

The budgetary technique involves the cost and return analysis. It is used to assess the profitability of female catfish farmers. It is given as:
$\mathrm{TR}=$

PQ........

(4)

Where

$\mathrm{II}=$ Total Profit $(\$)$

$\mathrm{TR}=$ Total revenue $(\$)$

$\mathrm{TC}=$ total Cost $(\$)$

$\mathrm{P}=$ Unit price of output (\$)

$\mathrm{Q}=$ Total quantity of output $(\mathrm{kg})$

Benefit-Cost Ratio $(B C R)=T R / T C$.

$\mathrm{II}=\mathrm{TRTC}$



Source: Facts about Delta State of Nigeria

Figure 1. Map showing the study area 


\section{Results and Discussion}

\section{Socioeconomic Characteristics of Female Fish Farmers}

The distribution of the women's fish farmers by age indicates that $7.1 \%$ of them were 20 to 30 years old and $15.2 \%$ were over 50 years old. Most (42.9 percent) of female fish farmers were between 41 and 50 years of age, and 31-40 years of age were closely followed by 34.8 percent .. The fish farmers' average age is 42 years old, which indicate that most farmers are in their working age. The outcome is a strong contrast according to Olowosegun et al. (2004).

The marital status would affect the level of obligation of the farmers, which could have a positive influence on their ability to participate in economic activities like fish farming. Most $(69.6 \%)$ of the women were married, $24.1 \%$ were single, while $2.7 \%$ were divorced and $3.6 \%$ were widowed. This is justified by the fact that the majority of women who participate in fish farming are married individuals. It also suggests that for these women, the means of subsistence is catfish farming. The implication is that married women will profit most from fish farming, as they tend to cater for their family. They can supply family labour easily.

The outcome indicates that $20.5 \%$ of female fish farmers had primary education, $60.7 \%$ had secondary education, and $12.5 \%$ had post-secondary education. Just about $6.3 \%$ were not formally educated. By implication, a reasonable number could understand and implement the advanced fishing technology available to achieve an improved in fish output. This implies that trained farmers predominantly engage fish farming and, for the most part, by those who are highly educated. This is because a great deal of technical and scientific knowledge is needed for fish production to be successfully carried out (Osondu et al. 2014). Thus, female catfish farmers would easily adopt new fishery technologies, which could improve their level of profit ceteris paribus.

It was evident that 43.8 percent of female fish farmers had been fishing for 1-5 years, 32.1 percent had 6-10years of experience, while 15.2 percent had 11-15 years of farming experience. The least constituted $1.8 \%$ with farming experience of above 20 years. The average farming experience is eight years. This is an indication that most female fish farmers have been involved in fish farming for a long time, which will have a positive impact on their production. This is due to the fact that the more experienced the farmers are, the more their ability to make decisions about fish farming as a measure of management ability. This is consistent with the finding by Onyekuru et al.(2019) that the more experience they have, the willingness to adopt the management methods of fish production become much easier.

From the result, about $57.1 \%$ of the female fish farmers had household size of $6-10$ persons and $41.1 \%$ of fish farmers had household size of $1-5$ persons. The lowest was $1.8 \%$ with a household size of 11-15 persons. The female fish farmers were noted to have an average household size of 6 individuals. This average is reasonably rational enough that most respondents in the study area would have necessitated the use of family labour. This is consistent with the findings of Gbigbi and Achoja (2020), who documented an average of 9 persons for backyard fish farmers in Nigeria (Table 1).

Table 1. Farmers socio-economic attributes $(\mathrm{N}=112)$

\begin{tabular}{|c|c|c|c|}
\hline Variables & Frequency & Percentage & Mean \\
\hline \multicolumn{4}{|l|}{ Age (years) } \\
\hline $20-30$ & 8 & 7.1 & \\
\hline $31-40$ & 39 & 34.8 & 42 years \\
\hline $41-50$ & 48 & 42.9 & \\
\hline $51-60$ & 14 & 12.5 & \\
\hline $61-70$ & 3 & 2.7 & \\
\hline \multicolumn{4}{|l|}{$\begin{array}{l}\text { Marital sta- } \\
\text { tus }\end{array}$} \\
\hline Married & 78 & 69.6 & \\
\hline Single & 27 & 24.1 & \\
\hline Divorced & 3 & 2.7 & \\
\hline Widowed & 4 & 3.6 & \\
\hline \multicolumn{4}{|l|}{$\begin{array}{l}\text { Education } \\
\text { level }\end{array}$} \\
\hline No schooling & 7 & 6.3 & \\
\hline $\begin{array}{l}\text { Primary } \\
\text { school }\end{array}$ & 23 & 20.5 & \\
\hline $\begin{array}{l}\text { Secondary } \\
\text { school }\end{array}$ & 68 & 60.7 & \\
\hline $\begin{array}{l}\text { Post-second- } \\
\text { ary }\end{array}$ & 14 & 12.5 & \\
\hline \multicolumn{4}{|l|}{$\begin{array}{l}\text { Experience } \\
\text { (years) }\end{array}$} \\
\hline $1-5$ & 49 & 43.8 & \\
\hline $6-10$ & 36 & 32.1 & 8 years \\
\hline $11-15$ & 17 & 15.2 & \\
\hline $16-20$ & 8 & 7.1 & \\
\hline Above 20 & 2 & 1.8 & \\
\hline \multicolumn{4}{|l|}{$\begin{array}{l}\text { Household } \\
\text { size }\end{array}$} \\
\hline $1-5$ & 46 & 41.1 & 6 persons \\
\hline $6-10$ & 64 & 57.1 & \\
\hline $11-15$ & 2 & 1.8 & \\
\hline
\end{tabular}




\section{Profitability Analysis of Female Fish Farmers}

Table 2 presents the expenses and return of catfish production. It indicates that $\$ 646,065$.78 was the total cost incurred by the female catfish farmers, of which the total variable cost accounting for the largest proportion, i.e. $88.5 \%$, whereas the fixed cost was the lowest, representing $11.5 \%$ of the total cost of fish production. Feed costs also accounted for $48.6 \%$ of the overall cost, and also the highest. The result shows that the revenue of $\$ 1,062,308.60 \mathrm{k}$ was realized. About $\$ 490,378.46$ and $\$ 416,242.82 \mathrm{k}$ were the gross margin and net farm profits. Positive net farm income infers that catfish farming is profitable.

It was estimated that the return on investment (ROI) and the benefit cost ratio were 0.64 and 1.64. As the BCR is greater than one, fish production is considered profitable. With about 64 per cent return on investment, the business is profitable.

The study suggests that $\$ 0.64$ was made as a profit for each $\$ 1.00$ spent on catfish farming. This finding is consistent with Gbigbi et al. (2019) assertion that aquaculture is a lucrative investment venture in cooperative fish farming, as supported by the BCR of N2.06.

Table 2. Profitability of female catfish farmers

\begin{tabular}{lll}
\hline Items & Amount (\$) & Percentage \\
\hline Variable cost & & \\
Fingerlings cost & 96949.16 & 15.0 \\
Feed cost & 313798.70 & 48.6 \\
Drugs/medication & 8423.96 & 1.3 \\
Water cost & 14100.00 & 2.2 \\
Lime cost & 13989.47 & 2.2 \\
Fertilizer cost & 10523.24 & 1.6 \\
Labour cost & 107345.61 & 16.6 \\
$\begin{array}{l}\text { Transportation } \\
\text { Total variable cost }\end{array}$ & 6800.00 & 1.1 \\
$\begin{array}{l}\text { Fixed cost } \\
\text { Land cost } \\
\text { (depreciation) }\end{array}$ & $4964,930.14$ & 88.5 \\
$\begin{array}{l}\text { Pond construction } \\
\text { (depreciation) }\end{array}$ & 22648.74 & \\
$\begin{array}{l}\text { Equipment } \\
\text { (depreciation) }\end{array}$ & 1844.32 & 7.7 \\
$\begin{array}{l}\text { Total fixed cost } \\
\text { Total cost }\end{array}$ & $74,135.64$ & \\
Total revenue & $646,065.78$ & 11.5 \\
Gross margin & $1,062,308.60$ & \\
$\begin{array}{l}\text { Net farm income } \\
\text { Return on invest- } \\
\text { ment }\end{array}$ & $490,378.46$ & \\
Benefit cost ratio & $416,242.82$ & \\
\hline
\end{tabular}

\section{Stochastic Frontier Model of Female Fish Farmers}

The Cobb Douglas production function's maximum probability estimate in Table 3 showed that total variance and gamma values were respectively 0.570 and 0.830 . At the $5 \%$ level, the total variance of 0.680 is statistically significant, suggesting a good fit and the accuracy of the stated distributional assumption of the composite error term. The findings disclosed that size of pond, fingerlings, quantity of feed and water supply were positive and significant at $1 \%$ and $5 \%$, while medication cost was negatively significant at $5 \%$.

The estimated coefficient with respect to pond size was 0.152 . This suggests that for every $1 \%$ increase in pond size, it would lead to $0.152 \%$ increase in output of fish. This shows that pond size must be increased to obtained increased efficiency level of fish farming. The explanation for this is that fish develop at varying rates and if the pond size were not expanded to accommodate the sizes then otherwise the fish would be excessively bigger which would in the long run lead to lower production. Increased pond size is thus a required prerequisite for increased fish production. This agreed with Gbigbi et al. (2017) findings.

The coefficient of fingerling stocking capacity was positively significant with a production elasticity value of 1.361 . Therefore, a $1 \%$ rise in stocking capability would raise fish production by $1.361 \%$. This reveals that by expanding farmland, there is space for increasing production. With previous works by Gbigbi (2019), this outcome agrees that the greater the stock size, the more successful a farmer becomes. This means that as the fish farmer buys more fingerlings, the efficiency of catfish production increases.

The relationship between feed and fish output was positive. This is anticipated because output levels are largely dependent on the extent of feed used on the farm. This result agrees with that of Baruwa and Omodara (2019).

The coefficient for medication (-2.540) for fish production carried negative signs and is significant at $5 \%$. This means that with every 1 percent increase in the cost of medication, the production output of fish will decrease by -2.540 percent.

The coefficient for water supply $(0.232)$ had positive relationship with output at $1 \%$. This indicates that increase in availability of water to the fishpond will lead to an increase in the output of fish. This agrees with Ekanem et al. (2012) study in Cross Rivers State that cost of water was significant in aquaculture production.

The inefficiency model showed that the age of the female fish farmers is negatively significant with efficiency at $5 \%$. The negative sign of age implies that as the farmer increases in 
age, she would gain more experience in farming which could increase farm technical efficiency in other words farm inefficiency will be reduced. This disagreed with the work of Gbigbi (2019).

The coefficient for education was found to be negatively significant at $1 \%$. It means that increase in educational status reduces female fish farmers' technical inefficiency. Educated female fish farmers will be able to readily adopt and utilize efficiently modern fish farming technologies, which results in higher productivity.

Household size had a negative coefficient, which was significant at 5\%. This means large households could serve as reservoir of family labour. Families with large households could be more efficient when it comes to supply of labour to achieve critical fish farm operations. This may hold, if the household members are willing to support their family fish farm enterprise. This agrees with Gbigbi and Enete (2014).

The variable distance was positively significant at $5 \%$. This implies that the farther the distance of farm from farmer's residence the higher the technical inefficiency. This support the findings of Gbigbi (2019).

Credit access had positive coefficient for the respondents. The positive signs recorded imply that the female fish farmers who have access to credit are more inefficient than those who do not have. This could be due to untimely access of the credit, which may lead to diversion of credit to other nonfishing activities. It was expected that if the credit is invested into fish production, it would have led to higher output level.

\section{Technical Efficiency Scores Index}

Table 4 presents the female catfish farmer's efficiency level. The efficiency level ranges from 36.5-89.1.' About 6.3\% of catfish farmers had technical efficiency ranging between 0 20 while $12.5 \%$ had technical efficiency ranging between 21 40. About $50 \%$ of the catfish farmers had technical efficiency ranging between 41-60 and about 32.2\% had technical efficiency above $60 \%$. The average technical efficiency value was about $53.5 \%$, indicating that the realized output could be increased by about $46.5 \%$ by adopting the fishing technologies of the best female fish farmers.
Table 3. Stochastic production function for female fish farmers

\begin{tabular}{|c|c|c|c|c|}
\hline Variables & Parameters & Coefficients & $\begin{array}{l}\text { Standard } \\
\text { error }\end{array}$ & t-value \\
\hline \multicolumn{5}{|l|}{$\begin{array}{l}\text { Production } \\
\text { factors }\end{array}$} \\
\hline Constant & $\mathrm{X}_{0}$ & 2.628 & 1.064 & $2.470 * *$ \\
\hline Pond size & $\mathrm{X}_{1}$ & 0.152 & 0.049 & $3.102 * *$ \\
\hline Labour & $X_{2}$ & 0.340 & 0.194 & 1.753 \\
\hline Fingerling & $X_{3}$ & 1.361 & 0.247 & $5.510 * * *$ \\
\hline Feed & $\mathrm{X}_{4}$ & 1.022 & 0.610 & $3.315 * * *$ \\
\hline $\begin{array}{l}\text { Medication } \\
\text { cost }\end{array}$ & $\mathrm{X}_{5}$ & -2.540 & 1.217 & $2.087 * *$ \\
\hline $\begin{array}{l}\text { Water sup- } \\
\text { ply }\end{array}$ & $\mathrm{X}_{6}$ & 0.232 & 0.053 & $4.377 * * *$ \\
\hline \multicolumn{5}{|l|}{$\begin{array}{l}\text { Ineffi- } \\
\text { ciency fac- } \\
\text { tors }\end{array}$} \\
\hline Constant & $\mathrm{Z}_{0}$ & 0.152 & 0.073 & $2.082 * *$ \\
\hline Age & $\mathrm{Z}_{1}$ & -1.059 & 0.372 & $2.847 * *$ \\
\hline Education & $\mathrm{Z}_{2}$ & -0.027 & 0.008 & $3.375 * * *$ \\
\hline $\begin{array}{l}\text { Household } \\
\text { size }\end{array}$ & $\mathrm{Z}_{3}$ & -0.232 & 0.103 & $2.252 * *$ \\
\hline $\begin{array}{l}\text { Fish } \\
\text { farming } \\
\text { experience }\end{array}$ & $\mathrm{Z}_{4}$ & 0.414 & 0.520 & 0.796 \\
\hline $\begin{array}{l}\text { Distance of } \\
\text { farm }\end{array}$ & $\mathrm{Z}_{5}$ & 0.249 & 0.108 & $2.306^{* *}$ \\
\hline $\begin{array}{l}\text { Credit } \\
\text { access }\end{array}$ & $\mathrm{Z}_{6}$ & 0.083 & 0.023 & $3.609 * * *$ \\
\hline $\begin{array}{l}\text { Diagnostic } \\
\text { statistics }\end{array}$ & & & & \\
\hline $\begin{array}{l}\text { Sigma } \\
\text { squared }\end{array}$ & $\sigma^{2}$ & 0.570 & 0.264 & $2.159 * *$ \\
\hline Gamma & $\Gamma$ & 0.830 & 0.211 & $3.934 * * *$ \\
\hline Log & & 64.104 & & \\
\hline $\begin{array}{l}\text { likelihood } \\
\text { function }\end{array}$ & & & & \\
\hline LR Test & & 9.320 & & \\
\hline
\end{tabular}

Table 4. Technical efficiency level of female fish farmers

\begin{tabular}{lll}
\hline Efficiency level & Frequency & Percentage \\
\hline $0-20$ & 7 & 6.3 \\
$21-40$ & 14 & 12.5 \\
$41-60$ & 56 & 50.0 \\
$61-80$ & 25 & 22.3 \\
$81-100$ & 10 & 8.9 \\
Total & 112 & \\
Maximum Technical & 89.1 & \\
efficiency & & \\
Minimum Technical & 36.5 & \\
efficiency & & \\
Mean & 53.5 & \\
\hline
\end{tabular}




\section{Elasticities of Production Inputs and Return to Scale of Female Fish Farmers}

Table 5 indicates the elasticity of inputs of output and the return to scale of female farmers. The sum of the input coefficients suggests a declining return to the scale of 0.567 and that women fish farmers are generally reasonably effective at using their input into output. However, the most productive use of variable inputs will be estimated by the relative unit prices of individual technical inputs. This indicates that there is a declining return to scale in catfish production.

The results are that each additional input unit leads to a marginal upsurge in the price of fish output compared to previous unit. In stage 2, the quantity of output elasticities is greater than zero but $<1$. This suggests that, in stage 2, production among fish farmers occurred at a reasonable stage of production. This implies that the higher the inputs used, the higher the output of fish, but at a lower cost. This finding is in consonance with Gbigbi (2019).

\section{Challenges Encountered by Female Fish Farmers}

The foremost constraints' limiting female catfish farmers is presented in Table 6. Inadequate finance (mean=2.9107), high cost of feed (2.8929), water supply(2.8839) and scarcity of fingerlings(2.8571) ranked 1st, 2nd, 3rd and 4th respectively as the most important areas where technical assistance is required by the respondents. This concurs with (Idoge et al 2017., Ohen and Abang 2009., Oyinbo et al. 2013., George et al. 2010) findings that fish production is affected by lack of adequate capital, high cost of feed, high cost of labour, inadequate water supply and theft.

\section{Conclusion}

The study concludes that by increasing pond size, fingerlings, feed quantity and water supply, there is potential for increasing female catfish farmers in Delta State, Nigeria. Technical efficiency ranged from 36.5 to 89.1 with a mean value of 53.5. This revealed that productivity can be improved further by 46.5 percent by raising awareness of modern fish culture technology and cost-efficient skills that will play a major role in improving female catfish farmers' fish productivity. The result indicates that insufficient financing, high feed costs, water supply and the shortage of fingerlings were the issues that made farmers' unable to hit the production frontier.

It was recommended that

i. More emphasis should therefore be placed on resource utilization to further sustain catfish production.

ii. Government should assist the female catfish farmers through soft loan

iii. Female catfish farmers should be encouraged through technical training on production practices that support the optimum use of their resources

iv. More female catfish farmers should also be encouraged to go into fish farming since it is profitable.

v. Government should provide subsidy to enable purchase feed at lower cost

vi. Government should embark on irrigation programme to facilitate water availability for sustainable production

vii. Government should assist the female farmers with consistent supply of fingerlings at subsidized rate

Table 5. Elasticities of production inputs and return to scale of female fish farmers

\begin{tabular}{ll}
\hline Variables & Coefficients \\
\hline Pond size & 0.152 \\
Labour & 0.430 \\
Fingerling & 1.361 \\
Quantity Feed & 1.022 \\
Drugs cost & -2.540 \\
Water supply & 0.232 \\
RTS & 0.567 \\
\hline
\end{tabular}

Table 6. Constraints faced by female fish farmers

\begin{tabular}{lllll}
\hline Constraints & Mean & Std. deviation & Remark & Ranking \\
\hline High cost of feed & 2.8929 & 0.31068 & Significant & $2^{\text {nd }}$ \\
Lack of modern technologies & 2.8036 & 0.48098 & Significant & $5^{\text {th }}$ \\
Water supply & 2.8839 & 0.34863 & Significant & $3^{\text {rd }}$ \\
Pond construction & 2.5625 & 0.58172 & Significant & $9^{\text {th }}$ \\
Inadequate finance & 2.9107 & 0.28644 & Significant & $1^{\text {st }}$ \\
Lack of fingerlings & 2.8571 & 0.42143 & Significant & $4^{\text {th }}$ \\
Cost of land & 2.7768 & 0.49701 & Significant & $6^{\text {th }}$ \\
Inadequate extension contact & 2.6875 & 0.52042 & significant & $8^{\text {th }}$ \\
High mortality rate & 2.7589 & 0.45014 & Significant & $7^{\text {th }}$ \\
\hline
\end{tabular}

Cut off point $=2.00$ Mean $>2.00=$ a problem, mean $<2=$ not a proble 


\section{Compliance with Ethical Standard}

Conflict of interests: The authors declare that for this article they have no actual, potential or perceived conflict of interests.

Ethics committee approval: This research was conducted with the approval of the ethics committee, Department of Agricultural Economics and Extension, Delta State University Asaba Campus on 22/04/2020(Ethical committee approval number: AEE/2020/012).

Funding disclosure: -

Acknowledgments: I hereby acknowledge the anonymous reviewers for their criticisms and contributions that have added value to this article. Thanks to all those whose materials were consulted in the course of this research.

Disclosure: -

\section{References}

Adebayo, O.O., Daramola, O.A. (2013). Economic analysis of catfish (Clarias gariepinus) production in Ibadan metropolis. Journal of Agriculture and Food Sciences, 1(7), 128134.

Adenugba, A.O., Raji-Mustapha, N.O. (2013). The role of women in promoting agricultural productivity and developing skills for improved quality of life in rural areas. IOSR Journal of Engineering, 3(8), 51-58.

https://doi.org/10.9790/3021-03855158

Adewale, J.G., Ikeola, R.F. (2005). Resettlement Coping Strategies of Women Settlers around Dams in Nigeria: A Case Study of Erelu Dam in Oyo, Oyo State, Nigeria. Journal of Human Ecology, 17(3), 177-181.

https://doi.org/10.1080/09709274.2005.11905777

Ani, A.O. (2004). Determinants of food crop output among rural women farmers in Ebonyi State Nigeria: implications for crop extension education. Journal of Sustainable Agricultural Environment, 5(2), 188-195.

Baruwa, O.I., Omodara, O.D. (2019). Technical efficiency of aquaculture system in Oyo State, Nigeria: Stochastic frontier approach. Journal of Aquatic Research \& Marine Sciences, 2(1), 114-120.

https://doi.org/10.29199/ARMS.103026

Central Bank of Nigeria (2011). Annual Report for the Year Ended 31st December. 2011.

Central Bank of Nigeria (2017). Annual Report for the Year Ended 31st December. 2017.
Cohen, P.J., Sarah, L., Michelle, D., Miranda, M., Enly, S., Helen, T., Paula, K. (2016). Understanding adaptive capacity and capacity to innovate in social-ecological systems: applying a gender lens. Ambio, 45(3), 309-321.

https://doi.org/10.1007/s13280-016-0831-4

Ekanem, E., Damian, A., Etim, G.R. (2012). Socioeconomic analysis of fish farming in Cross River State, Nigeria: Implication for Food Security Tropentag, Gottingen Resilience of agricultural systems against crisis, Nigeria. African Journal of Agricultural Research, 3, 246-254.

Ekunwe, P.A., Emokoro, C.O (2009). Technical Efficiency of Catfish Farmers in Kaduna, Nigeria. Journal of applied sciences research, 5(7), 802-805.

Eyo, A.A. (2003). Fundamental of fish nutrient and diet development - An overview In: A.A. Eyo (Ed). National workshop on fish feed development and feeding practices in aquaculture organized by Fisheries Society of Nigeria, New Bussa, Niger State, 2-6.

FAO (2003).Gender, Key to Sustainability and Food Security. Plan of Action. Gender and Development. Rome.

FAO (2017). The state of food security and nutrition in the World: Building resilience for peace and food security. Rome: Food and Agriculture Organization of the United Nations.

FDF (2007). Federal Department of Fisheries. Fisheries Statistics of Nigeria, Fourth Edition 1995-2007.

Gbigbi, T.M. (2017). Quantitative analysis of small scale catfish enterprises in Oshimili South Local Government Area, Delta State. Production Agriculture and Technology Journal (Pat), 13(1), 36-42.

Gbigbi T.M. (2019).Technical efficiency and artisanal fishing households: Any hope in oil extracting locations? Evidence from Nigeria. Ege Journal of Fisheries and Aquatic Sciences, 36(3), 219228.

https://doi.org/10.12714/egejfas.2019.36.3.03

Gbigbi, T.M. Achoja, F.O. (2020. Backyard fish farm features and farmers personal characteristics as correlates of profitability of aquaculture in Nigeria. Ege Journal of Fisheries and Aquatic Sciences, 37(3), 223-228. https://doi.org/10.12714/egejfas.37.3.03 
Gbigbi, T.M., Enete, A.A. (2014). Economic efficiency of artisanal fishery households under oil pollution environment in the Niger Delta Region of Nigeria. Tropicultura, 32(4),183-190.

Gbigbi, T.M., Achoja, F.O., Temile, S.O. (2019). Cooperative funding as driver of aquaculture development: Evidence from Nigeria, European Journal of Social Sciences, 58(2), 124-133.

Gbigbi, T.M., Taru, V.B., Obetta, A.E. (2017). Gender perspective of youth engagement in Aquaculture in Delta State, Nigeria. International Journal of Development Strategies in Humanities, Management and Social Sciences, 7(3), 112125.

George, F.O.A., Olaoye, O.J., Akande, O.P., Oghobase, R.R. (2010). Determinants of aquaculture fish seed production and development in Ogun State, Nigeria. Journal of Sustainable Development in Africa, 12(8), 22-34.

Idoge, D.E., Gbigbi, T.M., Aguegbe, T.O. (2017). Factors determining success of small scale fish farming enterprise in Warri Metropolis. Taraba Journal of Agricultural Research (TAJAR), 5(2), 1-8.

Krushelnytska, O. (2015). Toward gender-equitable fisheries management in Solomon Islands. Sydney. Retrieved from

http://documents.worldbank.org/curated/en/467721468187800125/pdf/98279-WP-P146728Box385353B-PUBLIC-ACS.pdf (accessed 15.02.2020).

Ohen, S.B., Abang, S.O. (2009). Economics of catfish farming in Rivers State Nigeria. Academic Journal of Plant Sciences, 2(1), 56-59.

Olowosegun, T., Sanni, A.O., Sule, A.M., Bwala, R.L. (2004). Contribution of Women to Fisheries development in Kainji Lake Basin, in 2004 FISON Conference proceedings, p. 91-97.

Osondu, C.K., Ijioma, J.C. (2014). Analysis of profitability and production determinants of fish farming in Umuahia capital territory of Abia State, Nigeria. World Journal of Agricultural Science, 2(7), 168-176.

Onyekuru, N.A., Ihemezie, E.J., Chima, C.C. (2019). Socioeconomic and profitability analysis of catfish production: A case study of Nsukka local government area of Enugu State, Nigeria. Journal of Tropical Agriculture, Food, Environment and Extension, 18(2), 51-58.

https://doi.org/10.4314/as.v18i2.9

Oyinbo, O., Rekwot G. Z (2013). Fishery production and economic growth in Nigeria: Pathway for sustainable economic development. Department of Agricultural Economics and Rural Sociology, Ahmadu Bello University, Nigeria. Journal of Sustainable Development in Africa, 5(2), 99-109.

Parks, M.H., Christie, M.E., Bagares, I. (2015). Gender and conservation agriculture: constraints and opportunities in the Philippines. GeoJournal, 80(1), 61-77.

https://doi.org/10.1007/s10708-014-9523-4

Shester, G.G., Micheli, F. (2011). Conservation challenges for small-scale fisheries: By catch and habitat impacts of traps and gillnets. Biological Conservation, 144(5), 16731681.

https://doi.org/10.1016/j.biocon.2011.02.023

Silvestre, G.T., Garces, L.R., Stobutzki, I., Ahmed, M., Santos, R.A.V., Luna, C.Z., Zhou, W. (2003). South and South-East Asian coastal fisheries: their status and directions for improved management: conference synopsis and recommendations. World Fish Center Conference Proceedings, 67, $1-40$.

Tsadu, S.M., Ojutiku, R.O., Anyawale, A.V. (2006). A survey of fungal contamination of some fish species from Tagwai Daru, Minna, Niger State, Nigeria. Journal of Tropical Biosciences, 6, 1-5.

Tulachan, M., Karki, S. (2000). Gender and Livestock Management in Mixed Farming Systems. ICIMOD Newsletter, No. 37. 